\title{
Analysis on the behavioral Pattern of Organized and Unorganized Vegetable Retail Shoppers
}

\author{
A. Anuradha
}

\begin{abstract}
In any marketing chain the consumer is the most important person. Consumer satisfaction is the ultimate objective of the marketing process. Farmers and those involved in marketing must be aware of consumer needs in order to produce and supply products that fulfill consumers' requirements. According to FAO (1999), marketing involves finding out what the consumers want and supplying it to them at a profit. Therefore the whole marketing process has to be consumer oriented. Producer must supply consumers with what they want or need. In the process of developing the vegetable sector in India, it is essential to consider the needs, preferences and behaviour of consumers. The main objective of this study is to find out the major factors influencing the purchase of vegetables in an Organised and Unorganised vegetable retail outlet. To statistically analyse the data, frequency distributions and Chi-squire test were used.The result shows that there is a significant positive relationship between the income level of the consumer and their preferred vegetable market place. Overall the freshness of the vegetables and the appearance (well cleaned and sorted vegetables) are found to be the major factors among the consumers in choosing an organised/Unorganised retail outlet.
\end{abstract}

Keywords--- Retailing, Organized Outlet, Unorganized Outlet, Consumption, Vegetables, Marketing

\section{INTRODUCTION}

$\mathrm{V}$ EGITABLES are one of the most needed and consumed items. Every household uses vegetables on daily basis though some buy them for 2-3 days given that they have the luxury of a refrigerator. Recently, in bigger cities, the difficulty in getting fresh vegetables, road congestion, office life-style, and shortage of time, generated a need of supermarkets. In these supermarkets, vegetables along with fruits made their entrance because the owners wanted to make these supermarkets one-stop-shop for their customers. Reliance Fresh and Spencer's are good examples of this concept.

Buyer motivations are quite complex and vary according to gender, age, cultural, ethnic, regional etc. The consumer attitudes do not follow a uniform pattern. One of the major consideration while buying the fruits and vegetables is the tangible quality attributes such as uniformity, freshness, quality, colour, ripeness, Packaging, etc which affect

A. Anuradha, Assistant Professor (Senior), Vellore Institute of Technology Business School,VIT University, Chennai.

DOI: 10.9756/BIJIEMS.8088 appearance and make produce more appealing or attractive compared to similar products. Though the above discussed are the major factors to influence the buyer decisions ,there are few other factors influencing the purchase of fruits and vegetables such as occupation, Income, awareness, duration of the purchase and Price in both the organised as well as the unorganised retail outlets.

\section{REVIEW OF LITERATURE}

Sanjeev Kapoor et. al [3] attempted to understand selected behaviors of fruit and vegetable consumers of mid-sized cities of a developing economy, which are important for any retailer to appreciate. The study was carried out in two mid-sized cities of the Orissa state of India with 100 respondents by using the specially developed questionnaire. Statistical tools were used to analyze the data. The study revealed that vegetables are consumed in greater quantity and purchased more frequently than fruits. The results of the study showed that the consumers attached more importance to credence attributes than to search and experience attributes while making their purchase decisions. Family income and consumers' education were found to have significant influence on the consumers' willingness to pay for graded and packaged products.

K. B. Ramappa, A. V. Manjunatha[2] have analysed the attitudes of the consumers' in Bangalore towards buying of fruits and vegetables and their choice of retail outlets. The primary data was collected from 100 consumers belonging to the Bangalore City during October 2014. Sample consumers buying at supermarkets, convenience stores and hypermarkets were purposively selected. The collected data was analyzed using descriptive statistics and multinomial logit model. It was found that among all variables, quality and prices were major accountable factors for buying fruits and vegetables at organized retail shops. The empirical result of multinomial logit model revealed that annual net income was positively associated with the Big Bazar and Food World consumers and negatively associated with the Reliance Fresh, More and Niligiris consumers, as compared with the HOPCOMS consumers.

B. Aparna and C.V. Hanumanthaiah[4] conducted a study to assess the impact of the upcoming supermarkets on farmers, consumers and different marketing channels in Rangareddy district of Andhra Pradesh which is operating their retail outlets in Hyderabad city.Raut and Dash [9] have pointed out the various aspect of segmentation and the consumer behavior aspect of retail buyers in India. PaulrajanRajkumar and Fatima Jacob [7], in their research on "Business models in vegetable retailing" opine that the retail sector in India is at the 
crossroads today. A shift between organised and unorganised retail sector is apparent, especially in the vegetable retailing zone. They found this shift as a call for transfer of consumerism towards organised retailing. They have said that the penetration of organised retail in the field of vegetable retailing will face fierce resistance from traditional retailers with their existing strong foothold.

Prof. BrajeshBoliya and MohitJain[8] K.J. Somaiya Institute of Management Studies and Research, believe that better knowledge of the consumer is the presumption for preparing the efficacious selling concept. Their analysis proved that $72 \%$ of consumers who do the purchase of fruits and vegetables were females. Almost $66 \%$ of the consumers visit another seller also, while $70 \%$ of the consumers visit the food bazaar twice and thrice in a week. In this research they found that biggest competitor for organized retailers is local vegetable market and the customers of food bazaar are middle class customers.

The US study by Lindsay et al. [10] investigates F\&V consumption as a function of consumption intention, consumption attitude and other variables which are postulated by the 'theory of planned behaviour'. The study finds the causal relationships between these variables partly differ significantly across different population segments. However, the study also finds that there is no significant link between attitudes and consumption intentions in half of the identified consumer segments.

As to Australian consumers, Nijmeijer et al.'s [5] study shows that there may be different reasons for buying different types of vegetables. The main reason which predicts consumption of all types of vegetables is preparation convenience.

Fruits consumption patterns in Japan have been analysed by Shim et al. [6]. Their study highlights the special role of aesthetics and food safety in the buying motivations of Japanese consumers. Consequently, prices and convenience properties have been found as being less important.

Dealing with UK consumers, Van der Pol and Ryan [15] find that product quality is rated as the most important purchasing criterion for $\mathrm{F} \& \mathrm{~V}$.

\section{METHODOLOGY}

Due to explanatory nature of the study, both cross sectional surveys and case studies were used.The total population is the shoppers of vegetable retail outlets of Coimbatore. Convenience sampling technique was used. Since the study includes the primary data a self designed questionnaire was used for collecting the data from 100 vegetable buyers in various Organised and Unorganised vegetable retail outlets in Coimbatore city. Descriptive statistics and Chi Square were used to show an overview of the vegetable market in the Coimbatore city.

\section{OBJective OF THE STUDY}

i. To find out the major factors influencing the purchase of vegetables in an Organised and /or Unorganised retail outlet ii. To study the relationship between income level of the consumer and his choice of vegetable retail Market.

iii. The major limitations of the study are as follows

- It is assumed that the respondents are true and honest in expressing their views.

- The study is applicable only to Coimbatore city and not to any other similar areas.

\section{RESULTS AND DISCUSSION}

According to FAO [12], marketing involves finding out what the consumers want and supplying it to them at a profit. Therefore the whole marketing process has to be consumer oriented. Production must supply consumers with what they want or need. This is the reason why people spend their money to purchase different goods.

The behaviour of the consumers is influenced by endogenous factors (those internal to the consumers) and exogenous factors (those external to the consumer). Exogenous factors include culture, reference group, family and socio-economic situation. Endogenous factors include needs and motives, learning, self-concept, personalities and attitudes [11].

\section{A. Socio-Economic Environment of the Consumers}

The socio-economic situation of consumers is a powerful tool for organising markets. People from the same social group tend to have similar behaviour, styles of living, and buying similar products from the same types of outlets. The variables used to stratify a population by social class or group normally include age, income, occupation, education, and family size. Therefore it is useful to examine these characteristics of consumers.

\section{i. Age as a Factor}

Consumers of different age groups obviously have very different needs and wants. Although people who belong to the same age group differ in many ways, they do tend to share a set of values and common cultural experiences that they carry throughout the life [1].

Table 1: Age Wise Classification of the Consumers

\begin{tabular}{|c|c|}
\hline Age category & Percentage \\
\hline$\leq 30$ years & 24.70 \\
\hline $31-50$ Years & 72.40 \\
\hline$\geq 51$ years & 02.90 \\
\hline
\end{tabular}

From table 1 it is clear that around three-quarters of the consumers were in the middle age category ie.,31 - 50 years. It is interesting to note that only a small percentage of consumers were over 51 years of age. It was discovered that the majority of the middle age group were more rational in their thinking, less aggressive, and broad minded.

\section{ii. Family Size}

The size of the family is an important factor because the buyer is just a person, but everyone in the family is a consumer. It is difficult to identify the tastes and needs of the individual members. However, the total requirement of vegetables per family can be estimated. 
Table 2: Family Size of the Consumers

\begin{tabular}{|c|c|}
\hline Family Size & Percentage \\
\hline$\leq 2$ members & 1.3 \\
\hline $3-5$ members & 88.3 \\
\hline $6 \leq-$ members & 10.5 \\
\hline
\end{tabular}

From table 2 it can be inferred that about eighty eight percent of the respondents have 3 - 5 members in the family. Moreover, the family is the main group that influences the behaviour of individual buyers. Most the families with young children would tend to buy vegetables that are preferred by children.

\section{iii. The Level of Formal Education}

The level of education of a person has a significant influence on his/ her behaviour. Hence, it is an important factor to consider when examining behavioural patterns.

Table 3: Classification of the Consumers based on their Education Level

\begin{tabular}{|c|c|}
\hline Education level & Percentage \\
\hline Primary School & 13.00 \\
\hline Higher secondary school & 15.50 \\
\hline UG Degree & 39.70 \\
\hline PG Degree & 31.80 \\
\hline
\end{tabular}

Huffman [14] suggests that education levels are an important variable governing the decision-making of an individual. Table 3 shows that majority of the consumers have had Under Graduation as their level of education. The higher the educational level of an individual, the higher the decision making power, because of the increased ability to think logically. Table 3 indicates that the majority of consumers have higher education levels and therefore, their decisionmaking patterns may be more rational.

\section{iv. Types of Occupation of the Consumers}

Table 4: Classification of the Consumers based on the type of their Occupation

\begin{tabular}{|l|c|}
\hline Type of occupation & Percentage \\
\hline Labour & 10.0 \\
\hline Teacher & 23.8 \\
\hline Businessman & 30.6 \\
\hline Professional & 16.8 \\
\hline Other & 18.8 \\
\hline
\end{tabular}

The information in Table 4 indicate that the selected sample of consumers include all the main categories of occupations. The distribution is dominated by the Businessman category and this type of occupation will tend to be associated with higher levels of income. So a consumer's occupation may influence their purchasing power, tastes and buying patterns.

\section{v. Income Level of the Consumers}

The income levels of consumers will reflect their purchasing ability. Additionally, their tastes and preferences may change according to the level of income.

Table 5: Income wise classification of the Consumers

\begin{tabular}{|c|c|}
\hline Income levels (Rs) & Percentage \\
\hline$\leq 6000$ & 17.2 \\
\hline $6001-12000$ & 56.9 \\
\hline$\geq 12001$ & 25.9 \\
\hline
\end{tabular}

The results in table 5 show that the majority of consumers (56.9 percent) belong to the middle class with a monthly income level of 6001 to $12000 \mathrm{Rs} /$ month. Considerable proportions of consumers (25.9 percent) earn an income of more than $12001 \mathrm{Rs} /$ month. If the sample is representative, it would suggest that the majority of consumers at these three markets possess a greater purchasing ability.

\section{vi. Information about the Main Purchaser}

Table 6 shows that about thirty seven percent of the interviewees have considered themselves as the main purchaser of vegetables. Thirty two percent indicated that their spouse was the main purchaser. According to the information, forty nine percent of the interviewees were males.

Table 6: Information about the Main Purchaser of Vegetables

\begin{tabular}{|c|c|}
\hline Main purchaser & Percentage \\
\hline Himself/Herself & 37.2 \\
\hline Spouse & 32.6 \\
\hline Children & 04.7 \\
\hline Other & 25.5 \\
\hline
\end{tabular}

\section{vii. Factors Influencing Preference of the Organised/} Unorganised Market(s)

It is important to identify the factors that the consumers consider as important when purchasing their vegetable requirements in any retail shop (Organized/Unorganized). Almost all the consumers confirmed that the quality of the product as the most important factor influencing their decision to purchase (table 7). About sixty two percent considered low price and sixty three percent were concerned aboutthe freshness of the vegetables asthe most important facts. The latter has a direct influence on the quality of the product.

Table 7: Preference of the Market by the Consumers

\begin{tabular}{|l|c|}
\hline \multicolumn{1}{|c|}{ Factors } & Percentage response* \\
\hline Good Quality & 98 \\
\hline Low Price & 62 \\
\hline Variety of Vegetables & 53 \\
\hline Freshness & 63 \\
\hline Low Chemical exposure & 38 \\
\hline Regular availability & 43 \\
\hline
\end{tabular}

*Due to multiple responses the total is not equal to 100.

About thirty eight percent of consumers considered health and safety factors in the production of vegetables such as appropriate use of agro-chemicals. This is an unsatisfactory trend which may require campaigning to improve the consumers' awareness about the importance of the safe and healthy foods. A considerable proportion of consumers were interested in the selectivity of the vegetables (fifty three percent).

\section{viii. Main Market Places Visited by Consumers}

It is useful to have an idea about the main types of marketplaces visited by the consumers to purchase vegetables. Each respondent was required to indicate from which market the majority of their vegetables were purchased. The responses were evenly distributed among the different types of market places. The highest preference was given to the Organised super markets (twenty seven percent) while the least 
preference was given to the local Unorganised vegetable retailer (twenty percent). These results suggest that in planning the marketing of the vegetables, equal consideration should be given to these four marketplaces (Table 8).

Table 8: Vegetable Market Places Visited by the Consumers

\begin{tabular}{|l|c|}
\hline \multicolumn{1}{|c|}{ Market places } & Percentage \\
\hline TK Market(City Main market) & 21.3 \\
\hline Sandhai /Weekly fair & 24.3 \\
\hline Local Unorganised Vegetable retailer & 20.1 \\
\hline Organized Super markets & 27.2 \\
\hline Others & 7.1 \\
\hline
\end{tabular}

ix. $\quad$ Criterion for the Preference of Vegetables

These are some differences as well as similarities between the factors affecting consumer preferences in the place of purchase and the vegetables selected. In most occasions there is a relationship between the preferred market place and the characteristics of the vegetables. This kind of a relationship is difficult to prove using statistical tests. However, over a period of time the researcher has observed such a relationship. One example would be that the consumers preferred to go to markets with the intention of purchasing high quality and fresh vegetables.

Table 9: Criterion for the Preference of Vegetables

\begin{tabular}{|l|c|}
\hline \multicolumn{1}{|c|}{ Market place } & Percentage \\
\hline Appearance & 80 \\
\hline Freshness & 92 \\
\hline Price & 68 \\
\hline Nutritive value & 54 \\
\hline Organic vegetables & 28 \\
\hline Other & 34 \\
\hline
\end{tabular}

Table 9 shows that ninety two percent and eighty percent of consumers were concerned about the freshness and appearance of vegetables respectively. A much smaller proportion of consumers were concerned about the nutritional and hygienic (free of chemicals) value of vegetables. In this respect, consumers perhaps need to be educated about these factors using mass media and other modes of communication, since these two factors are important in the maintenance of satisfactory health in human beings. Children could be educated about these in school and then transfer these ideas to adults.

\section{x. Willingness to Pay Higher Prices for Quality Products}

Table 10: Consumers' Willingness to Pay Higher Prices for Quality Vegetables

\begin{tabular}{|c|l|}
\hline Willingness to pay a higher price for better Quality & Percentage \\
\hline Yes & 79.5 \\
\hline No & 20.5 \\
\hline
\end{tabular}

The majority of the consumers (79\%) have confirmed that they are willing to pay higher prices for quality products. Three characteristics of vegetables were used as a measure of quality: Freshness, Nutritive value, Hygienic factors.

\section{B. The Relationship between the Income Level and the Main Marketplace}

Table 11: The Relationship between Income Levels and the Main Market Place of Consumers

\begin{tabular}{|c|c|c|l|l|c|}
\hline \multirow{2}{*}{$\begin{array}{c}\text { Income } \\
\text { Level } \\
\text { (Rs) }\end{array}$} & $\begin{array}{l}\text { TK } \\
\text { Market } \\
\text { (City } \\
\text { Main } \\
\text { Market) }\end{array}$ & $\begin{array}{l}\text { Sandhai/ } \\
\text { Weekly } \\
\text { Fair }\end{array}$ & $\begin{array}{l}\text { Local } \\
\text { Unorganised } \\
\text { Retailer }\end{array}$ & $\begin{array}{l}\text { Organised } \\
\text { Supermarket }\end{array}$ & Others \\
\hline$\leq 6000$ & 0.0 & 87.8 & 12.2 & 0.0 & 0.0 \\
\hline $\begin{array}{c}6001- \\
12000\end{array}$ & 36.8 & 15.4 & 28.7 & 8.1 & 11.0 \\
\hline$\geq 12001$ & 1.6 & 1.6 & 6.5 & 87.1 & 3.2 \\
\hline
\end{tabular}

$\mathrm{X}^{2}=251.281$

$\mathrm{P}=0.000$

Table 11 shows that there is a significant positive relationship between the income level of consumers and their preferred Vegetable marketplace. Eighty seven percent of those in the higher income category fulfil their needs from Organised retail supermarkets. Eighty seven percent of the lower income category people visit a Sandhai or weekly fair to purchase their vegetables. This may be because in general, the prices of vegetables are low in Sandhai compared to other outlets. The lowest income group indicated that they never use city markets or supermarkets. The majority of middleincome people used city markets as their marketplace

\section{CONCLUSION}

The production of vegetables in India is a major political issue due to the following factors.

1. It has a direct influence on the cost of living of the people and their life expectancy. It is responsible for providing employment to several sectors such as farmers, wholesalers, collectors, auctioneers, retailers and input suppliers.

2. It has a direct impact on the national economy and on the country's export potential as people are more concerned about consuming vegetables that are not grown using harmful chemicals or fertilizers ie., organic vegetables. Therefore, it is essential to consider the behaviour of consumers to improve the attempts of those involved in the production and distribution of vegetables to meet the needs of consumers. Only in this way the vegetable producing and marketing enterprises will be able to satisfy the needs and wants of consumers.

\section{REFERENCES}

[1] Soloman, R. M., 'Consumer Behaviour’, New Jersey, USA.1999

[2] K. B. Ramappa, A. V. Manjunatha,' Fruits and Vegetable Consumers' Behaviour towards Organised Retailers: Evidence from India', International Science Index Vol:2, No:6,2015

[3] Sanjeev Kapoor \&Niraj Kumar, Fruit, 'Vegetable Consumers’ Behavior: Implications for Organized Retailers in Emerging Markets', Journal of International Food \&Agri business Marketing, Volume 27, Issue 3, P 203-227,2015

[4] Aparna and C.V. Hanumanthaiah, 'Organised Retailing of Vegetables: A Farmer, Retailer and Consumer Perspective in India', AmericanEurasian J. Agric. \& Environ. Sci., Vol.13, No 9: P-1258-1265, 2013 
[5] Marieke Nijmeijer, Anthony Worsley, Brian Astill, "An exploration of the relationships between food lifestyle and vegetable consumption", British Food Journal, Vol. 106 Iss: 7, pp.520 - 533,2004.

[6] Shim, S., K.C. Gehrt, and S. Holikova, "Shopping orientation-based segmentation of US groceryshoppers, Journal of Food Products Marketing, 5 (2), 1-19,1998

[7] Paulrajan Rajkumar and Fatima Jacob, 'Business Models of Vegetable Retailers in India', Department of Management Studies, Anna University, Chennai, India', Great Lakes Herald Vol 4, No 1.2010

[8] Prof. Brajesh Boliya and Mohit Jain, K.J., 'Buying behavior in fruit and vegetable category', Seminar paper, Somaiya Institute of Management Studies and Research, 2010

[9] Raut Manmath and DashSaroj Kumar, 'The Factors predicting Buying Behavior in Organized Retailing', International Journal of Business and Management Tomorrow Vol. 1 No. 3, p-2, 2011

[10] Lindsey Christian Fischer, IAMA, 'Opportunities for innovation in F\&V retailing: A Value chain approach', 2009

[11] Crawford, I. M., 'Agricultural and Food marketing Management', FAO, Rome, 1997

[12] Food and Agricultural Organization, 'Horticultural marketing a resource and training manual for extension officers', Rome, 1999

[13] Food and Agricultural Organization, 'A market oriented approach to post harvest management', AGSM Occasional paper No: 5, Rome, 1991

[14] Huffman, W.E., 'Decision making: The role of education'. American Journal of Agricultural Economics, 56(1), pp 85-97, 1974

[15] Van der Pol and Ryan, Using conjoint analysis to establish consumer preferences for fruit and vegetable, British food Journal, Vol 98, issue, 8, pp 5-12, 1996.

[16] Rohana P Mahaliyanaarachchi, ‘ The Impact of the Behavioural Patterns of Vegetable Consumers on Marketing Activities', Department of Agri business Management, Sabaragamuwa University of Sri Lanka, Conference Paper, 2000

[17] Rupasena L. P, 'Production and Marketing of Vegetables', Research study No. 102, HARTI, Colombo, 1999

A. Anuradha is an Assistant Professor (Senior) in Vellore Institute of Technology Business School, VIT University, Chennai, Tamil Nadu, India. She has received her Doctoral degree in Marketing from Bharathiar University, Coimbatore, Tamil Nadu, India, after her M.Phil degree in Strategic Marketing Management. She has done her MBA in Marketing and M.Sc in Economics from Avinashilingam University, Coimbatore, Tamil Nadu, India. She has 3 years of industry experience and a teaching experience of over 7 years in the fields of Marketing and Economics. Her research interest includes retailing and supply-side economics using quantitative techniques. She has actively contributed research articles in various international and national journals and conferences. (E-mail:anuradha.a@vit. ac.in) 